\title{
HISTORIS ATAU BIOGRAFI
}

OLEH : Asse Ananda \& Nurul Ahyunina

Prodi :Ekonomi Syariah

\section{Penelitian Kualitatif}

Penelitian kualitatif merupakan metode yang lebih mengedepankan khas-nya setiap apa-apa yang melekat pada sebuah fenomena, berupa pelaku fenomena, penyebab fenomena, dampak fenomena, hubungan fenomena, dan semua hal yang melekat pada fenomena itu sendiri. Menurut Linda Finley dalam bukunya "Going Exploring": The Nature of Qualitative Research", Qualitative Research for Allied Health Professionals: Challenging Choices. Yang diterbitkan di New York oleh penerbit John Wiley \& Sons Ltd metode kualitatif adalah penelitian yang dilakukan dalam setting tertentu yang ada dalam kehidupan riil (alamiah) dengan maksud menginvestigasi dan memahami fenomena: apa yang terjadi, mengapa terjadi dan bagaimana terjadinya?. Jadi riset kualitatif adalah berbasis pada konsep "going exploring" yang melibatkan in-depth and case-oriented study atas sejumlah kasus atau kasus tunggal.

Pada jurnal Edu-Bio; Vol. 4, Tahun 2013 M. Syahran Jailani dalam Abstrak tulisan yang berjudul Ragam Penelitian Qualitative menyebutkan Penelitian kualitatif itu berangkat dari fenomena yang ditemukan dilapangan kemudian dikembangkan pemahaman secara mendalam, alamiah, melibatkan konteks secara penuh, data dikumpulkan langsung dari partisipan langsung. Ini memperjelas bahwa metodologi kualitatif mengukur makna, sedangkan kuantitatif mengukur angka.

Dalam bukunya yang berjudul Qualitative Inquiry \& Research Design ;Chosing Among Five Approaches, John W Creswel mmenyajikan lima 
pendekatan penelitan kualitatif, Slection of the Five Aprroaches yang dimaksudkannya; Narative Research Phenomenology; Grounded Theory; Etnography dan Cash study.

\section{Pengertian Penelitian Biografi}

Pada tugas ini, tidak hanya memandang cara-cara kualitatif yang dipaparkan oleh Creswell untuk dikemukakan, ada metode biografi yang akan dipaparkan sebagaimana juga Cresswell menyebutkan biography dalam pengantar buku edisi keduanya. Dari pemaparan di atas, selanjutnya penulis akan menjelaskan metodologi penelitian kualitatif yaitu; Biografi

Biografi secara kualitatif merupakan studi pengalaman seorang individu yang diceritakan oleh peneliti atau ditemukan diberbagai dokumen atau arsip. Denzin (1989a) mendefinisikan metode biografi sebagai "studi yang menggunakan kumpulan dokumen yang mendeskripsikan kejadiankejadian dalam hidup seseorang". Sedangkan Creswell menggunakan beberapa jenis dalam penulisan biografi; seperti biografi individu, autobiografi, sejarah hidup, dan sejarah lisan terhadap individu serta pengalamannya yang dituliskan dengan cara mengumpulkan dokumen dan arsip-arsip. Tujuan penelitian ini adalah mengungkap pengalaman menarik yang dapat mempengaruhi atau mengubah hidup seseorang. Peneliti menginterpretasi subjek seperti subjek tersebut memposisikan dirinya sendiri.

Pada tulisan Safari Daud, biografi merupakan riwayat hidup tokoh yang ditulis oleh orang lain baik tokoh tersebut masih hidup atau sudah meninggal. Sedangkan riwayat hidup yang ditulis sendiri disebut otobiografi. (Daud, Safari, 2013). Pada daur hidup seseorang, kelahiran sampai kematian, ada banyak kejadian yang dialami oleh individu. Pengalaman ini merupakan unsur yang sangat menarik untuk diketahui, dengan metode biografi pengalaman 
yang terakumulasi direkam dan dipaparkan. Inilah yang membuat biografi merupakan sejarah individual menyangkut tahapan kehidupan dan pengalaman seseorang yang dialami dari waktu ke waktu.

Ada beberapa varian dalam metode biografi yang dijelaskan Daud, selain Biografi, ada otobiografi, Prosofografi dan Memoar. Jika biografi ditulis oleh orang lain, Otobiografi dituliskan oleh individu itu sendiri. Sangat mirip dengan memoar, bedanya pada fokus individu terhadap suatu kejadian atau fenomena saja. Pengelompokan tokoh tokoh atau individu mengenai cerita kehidupannya (Daud menyebutnya biografi kolektif) disebut dengan Prosofografi.

Kuntowijoyo dalam tulisan Daud memberikan dua macam biografi yaitu portrayal (portrait) dan scientific (ilmiah). Biografi dalam potret portrayal menurut Kunto adalah kategori biografi dalam potret hanya mencoba memahami, kecenderungan metode biografi ini pada makna memahami sang tokoh sekaligus memberi makna. Biografi scientific menurut Kunto merupakan usaha menerapkan tokoh berdasarkan analisis ilmiah dengan penggunaan konsep-konsepo tertentu sehingga menjadi sejarah yang menerangkan. Dalam ranah komunikasi, Biografi dapat dilakukan dalam penelusuran tokoh dan pemikirannya sekaligus, yang mempengaruhi komunikasi baik secara keilmuan maupun praktek komunikasi. Bahan yang digunakan dalam metode biografi ini adalah dokumen (termasuk surat-surat pribadi), wawancara, tidak hanya dengan orang yang bersangkutan, tetapi juga dengan orang yang disekelilingnya dan lainnya.

Biografi merupakan riwayat hidup tokoh yang ditulis oleh orang lain baik tokoh tersebut masih hidup atau sudah meninggal. Sedangkan riwayat hidup yang ditulis sendiri disebut otobiografi. Otobiografi lebih bersifat pengalaman nyata. Biografi tidak selamanya ditulis secara mandiri atau menjadi karya ilmiah sejarah yang terbebas dari intervensi siapapun. Gerry melihat bahwa sebagian besar biografi di indonesia merupakan tulisan 
biografi dalam bentuk pesanan (authorized biographies) yang menimbulkan kesan penonjolan diri. Sedangkan tulisan riwayat hidup kelompok atau biografi kolektif dikenal dengan prosopografi atau tabaqat dalam historiografi islam.

Biografi yang ditulis sejarawan lebih menunjukkan pada biografi ilmiah (scientific). Sedangkan penulis lainya lebih menunjukkan kepada jenis portrayal atau sebatas memahami tokoh saja. Anhar Gongong dalam menulis biografi Abdul Qahhar Mudzakkar terlebih dahulu membangun teori. Anhar tidak membiarkan varian-varian sejarah menjadi rumit dan memudahkannya dengan menemukan suatu alat pendekatan teori. la menggunakan teori kejiwaan atau deprivasi relatif yang didalamnya terkandung nilai antara kemampuan (kapasitas) dan ekspektasi (harapan). Selain itu, Anhar juga menggunakan teori collective behaviour (perilaku kolektif), yaitu teori mobilitas yang disarkan atas keyakinan (belief).

Secara khusus, Anhar juga memakai pendekatan budaya yaitu siripesse dalam masyarakat Bugis. Menurutnya, faktor budaya masyarakat setempat yang disebut sirri'na pace (siri'-pecce) adalah salah-satu komonenkomponen lain yang menjadi pemicu pemberontakan. Satu bab tersendiri dalam biografi Abdul Qahhar ini, penulis biografi membicarakan masalah siripesse. Nampak dalam biografi yang ditulis Anhar ini sudah membangun perspektif historiografi modern. Biografi ilmiah ini mengena pada pendekatan sejarah kejiwaan (psiko-historis), yaitu suatu analisis terhadap dinamika kejiwaan Qahhar Mudzakkar. Perilaku kolektif pengikut ditarik pada psikologi sejarah yang menuntut penjelasan seputar motivasi, sikap dan tindakan kolektif. Pendekatan tindakan kemanusiaan kolektif yang dilakukan Anhar dapat dimasukkan dalam hal ini. Sisi kedua, peristiwa politik ini dapat dijelaskan dalam sejarah kebudayaan lokal. Penamaan sejarah kebudayaan lokal dalam menerjemahkan siri' pesse akan melunakkan pengertian politik tentang adanya pemberontakan daerah yang bersifat administratif. 
Metode penelitian yang digunakan dalam ilmu tertentu sangat tergantung pada objek formal ilmu yang bersangkutan. Demikian halnya dengan study tokoh Pemikir Islam, karena objek formal yang khas, membawa konsekuensi bagi metodologi study dan penulisan karya ilmiah dalam bidang ini. ilmu penelitian modern membagikan penelitian menjadi lima macam yaitu penelitian sejarah, deskripsi, eksperimen mental, grounded research, dan tindakan. Diantara ciri yang menonjol dari penelitian sejarah adalah penyelidikan kritis mengenai pemikiran yang berkembang dijaman lampau dan mengutamkan data primer.

Pemikiran biografis, yaitu pemikiran terhadap kehidupan seorang tokoh dalam hubungannya dengan masyarakat sifat-sifat, watak, pengaruh pemikiran idenya, dan pembentukan watak tokoh tersebut selama hayatnya

Penulisan biografi memiliki akar disiplin yang berbeda dan ditemukan ketertarikan yang baru di beberapa tahun ini. Para cendekiawan menemukan tradisi baru terkait dengan biografi yang ditemukan dalam prespektif sastra, sejarah, antropologi, psikologi, dan sosiologi. Dapat dikatakan bahwa biografi hampir menjangkiti setiap aspek keilmuan yang ada.

Denzin (1989a) merangkum beberapa tipe dan karakteristik dalam biografi:

1. Dalam studi biografi, kisah hidup seseorang ditulis oleh orang lain dengan menggunakan dokumen ataupun rekaman yang tersimpan.

2. Dalam autobiografi, orang menuliskan kisah hidupnya sendiri.

3. Dalam sejarah hidup, peneliti melaporkan kehidupan seseorang dalam refleksi kebudayaan, kehidupan di masyarakat, kehidupan pribadi, kehidupannya di institusi, dan sejarah sosial (Cole, 1994).

4. Dalam sejarah lisan, peneliti mengumpulkan data berdasarkan kejadian-kejadian, penyebab kejadian tersebut, dan efeknya terhadap individu yang akan diteliti yang didapatkan dari seseorang atau beberapa orang. Informasi ini didapatkan melalui rekaman 
atau laporan tertulis dari orang tersebut baik yang sudah meninggal ataupun yang masih hidup.

Biografi juga dapat ditulis secara "objektif," dengan interpretasi peneliti; "berpendidikan," dengan asal-usul sejarah yang kuat berdasarkan subjek dan kronologi; "artistik," dari prespektif yang mengangkat ketertarikan tentang kehidupan; atau secara "naratif," memiliki karakter atau kejadian yang fiksi. Dalam biografi klasik, peneliti menggunakan pernyataan tentang teori, berfokus pada validitas dan dokumen, san rumus dalam hipotesis, semuanya berdasarkan prespektif dari peneliti. Dalam biografi interpretatif, membedakan antara asumsi yang teridentifikasi secara baik.

\section{Riset Biografi}

Riset biografi memfokuskan pada studi atas seseorang (individu) atau pengalaman sesorang yang diceritakan kepada peneliti atau diperoleh melalui dokumentasi dan atau arsip. Denzin (1989a) mendefinisikan metode biography sebagai "studied use and collection of life documents that describe turning point moments in an individual's life. Studi ini mengeksplorasi kehidupan seseorang yang sedang tenar atau terkenal, seorang yang marginal, seorang negarawan, manajer yang sukses, orang kaya raya dan seorang yang fenomenal. Kesemuanya ini dapat juga berupa biografi, otobiografi, life history dan oral history. Bahkan secara khusus Denzin menyebutkan pula bentuk „interpretive biografi". Interpretif biografi meletakkan pemahaman dan pengalaman seseorang kepada peneliti. "We create the persons we write about, just as they create themselves when they engage in storytelling practices".

Tulisan biografi mempunyai akar disiplin ilmu yang beragam dan padatahun belakangan ini telah banyak penelitian dan bahkan disertasi tentang ini (lihat Gaffikin, 1986). Pada awalnya metode ilmiah ini telah menjadi tradisi metode di disiplin ilmu history, antropologi, sosiologi dan psikologi. Namun belakangan telah banyak metode ini diadopsi oleh ilmu 
social lain termasuk sains akuntansi.

Secara khusus pemahaman metode biografi ini terinspirasi dari perspektif sosiologi yang dikembangkan oleh Plummer (1983) dan Denzin (1989a, b). Plummer (1983) mengkonsentrasikan pada evolusi "documents of life" research. Sementara Denzin memfokuskan pada "history of a life". Biografi itu sendiri telah mempunyai beberapa pencabangan metode yang satu dengan yang lain mempunyai tipikal yang berbeda-beda, yang terdiri dari metode biografi, otobiografi, life history dan oral history. Biografi menitikberatkan pada sejarah kehidupan seseorang yang ditulis oleh peneliti lain. Metode ini lebih populer dibandingkan dengan yang lain sebab banyak penelitian ilmiah dilakukan dengan metode ini terutama di US, AUS dan Europan Universities.

Life history adalah jenis metode yang juga populer dikalangan peneliti tingkat master dan doktor di banyak perguruan tinggi di Negara-negara maju. Life history merupakan pendekatan penelitian biografi yang ditemukan di social sciences dan anthropology. Life history menekankan bahwa seorang peneliti melaporkan tentang kehidupan individu dan bagaimana hal itu direflesikan dengan tema-tema kultur yang berkembang di masyarakat, tema-tema personal, tema-tema institusional dan tema-tema social history. Oral history membedakan pada pendekatan bahwa peneliti mengumpulkan data personal tentang kejadian, sebab akibat atau pengaruh seseorang atau beberapa orang. Data ini dapat berupa dokumen yang telah ditulis oleh orang yg sudah meninggal dunia atau mereka yang masih hidup (Eko Ganis Sukoharsono).

\section{Pengertian Penelitian Historis}

Yaitu suatu metode penelitian yang meneliti sesuatu yang terjadi di masa lampau. Dalam penerapannya, metode ini dapat dilakukan dengan suatu bentuk studi yang bersifat komparatif-Historis, yuridis, dan blbliografik. Penelitian $\mathrm{h}$ istoris bertujuan untuk menemukan generalisasi dan membuat rekrontruksi masa lampau, dengan cara memgumpulkan, mengevaluasi, 
memverivikasi serta mensintesikan bukti-bukti untuk menegakkan fakta-fakta dan bukti-bukti guna memperoleh kesimpulan yang kuat ( suryana 2010).

Secara umum dapat dimengerti bahwa penelitian historis merupakan penelaahan serta sumber-sumber lain yang berisi informasi mengenai masa lampau dan dilaksanakan secara sistematis. Atau dapat dengan kata lain yaitu penelitian yang bertugas mendeskripsikan gejala, tetapi bukan yang terjadi pada waktu penelitian dilakukan. Penelitian historis di dalam pendidikan merupakan penelitian yang sangat penting atas dasar beberapa alasan. Penelitian historis bermaksud membuat rekontruksi masa latihan secara sistematis dan objektif, dengan cara mengumpulkan, mengevaluasi, mengverifikasikan serta mensintesiskan bukti-bukti untuk mendukung buktibukti untuk mendukung fakta memperoleh kesimpulan yang kuat. Dimana terdapat hubungan yang benar-benar utuh antara manusia, peristiwa, waktu, dan tempat secara kronologis dengan tidak memandang sepotong-sepotong objek-objek yang diobservasi.

Menurut Jack. R. Fraenkel \& Norman E. Wallen, 1990 : 411 dalam Yatim Riyanto, 1996: 22 dalam Nurul Zuriah, 2005: 51 penelitian sejarah adalah penelitian yang secara eksklusif memfokuskan kepada masa lalu. Penelitian ini mencoba merenkonstruksi apa yang terjadi pada masa yang lalu selengkap dan seakurat mungkin, dan biasanya menjelaskan mengapa hal itu terjadi. Dalam mencari data dilakukan secara sistematis agar mampu menggambarkan, menjelaskan, dan memahami kegiatan atau peristiwa yang terjadi beberapa waktu lalu. Sementara menurut Donald Ary dkk (1980) dalam Yatim Riyanto (1996: 22) dalam Nurul Zuriah, 2005: 51 juga menyatakan bahwa penelitian historis adalah untuk menetapkan fakta dan mencapai simpulan mengenai hal-hal yang telah lalu, yang dilakukan secara sistematis dan objektif oleh ahli sejarah dalam mencari, mengvaluasi dan menafsirkan bukti-bukti untuk mempelajari masalah baru tersebut.

Berdasarkan pendangan yang disampaikan oleh para ahli diatas, dapat 
disimpulkan bahwa pengertian penelitian sejarah mengandung beberapa unsur pokok, yaitu

- Adanya proses pengkajian peristiwa atau kejadian masa lalu (berorientasi pada masa lalu);

- Usaha dilakukan secara sistematis dan objektif;

- Merupakan serentetan gambaran masa lalu yang integrative anatar manusia, peristiwa, ruang dan waktu;

- Dilakukan secara interktif dengan gagasan, gerakan dan intuiasi yang hidup pada zamannya (tidak dapat dilakukan secara parsial).

\section{Tujuan Penelitian Historis}

Adapun yang menjadi tujuan penelitian sejarah atau historis adalah untuk memahami masa lalu, dan mencoba memahami masa kini atas dasar persitiwa atau perkembangan di masa lampau (Jhon W. Best, 1977 dalam Yatim Riyanto, 1996: 23 dalam Nurul Zuriah 2005: 52).

Sedangkan Donal Ary (1980) dalam Yatim Riyanto (1996: 23) dalam Nurul Zuriah (2005: 52) menyatakan bahwa penelitian historis untuk memperkaya pengetahuan peneliti tentang bagaiman dan mengapa suatu kejadian masa lalu dapat terjadi serta proses bagaimana masa lalu itu menjadi masa kini, pada akhirnya, diharapkan meningkatnya pemahaman tentang kejadian masa kini serta memperolehnya dasar yang lebih rasional untuk melakukan pilihan-pilihan di masa kini.

Berikutnya Jack R. Fraenkel dan Norman E. Wellen (1990) dalam Yatim Riyanto (1996: 23) dalam Nurul Zuriah (2005: 52) menyetakan bahwa para peneliti pendidikan sejarah melakukukan penelitian sejarah dengan tujuan untuk:

- Membuat orang menyadari apa yang terjadi pada masa lalu 
sehingga mereka mungkin mempelajari dari kegagalan dan keberhasilan masa lampau;

- Mempelajari bagaiman sesuatu telah dilakukan pada masa lalu, untuk melihat jika mereka dapat mengaplikasikan maslahnya pada masa sekarang;

- Membantu memprediksi sesuatu yang akan terjadi pada masa mendatang;

- Membantu menguji hipotesis yang berkenaan dengan hubungan atau kecendrungan. Misalnya pada awal tahun 1990, mayoritas guru-guru wanita datang dari kelas menengah ke atas, tetapi guru laki-laki tidak;

- Memahami praktik dan politik pendidikan sekarang secara lebih lengkap.

- Dengan demikian, tujuan penelitian sejarah tidak Idapat dilepaskan dengan kepentingan masa kini dan masa mendatang.

\section{Jenis- jenis Penelitian Historis}

Penelitian historis sangat banyak sekali macamnya. Akan tetapi secara mum penelitian historis dibagi menjadi empat jenis, yaitu sebagai berikut:

- Penelitian historis komparatif

Penelitian sejarah komparatif adalah metode penelitian sejarah yang dikerjakan untuk membandingkan faktor-faktor dari fenomena-fenomena sejenis pada suatu periode masa lampau. Misalnya, ingin diperbandingkan sistem pengajaran dicina dan dijawa pada masa kerajaan majapahit.

- Penelitian yuridis atau legal

Jika dalam metode sejarah diinginkan untuk menyelidiki 
hal-hal yang menyangkut dengan hukum, baik hukum formal maupun nonformal pada masa yang lalu, maka penelitian yang demikian tergolong penelitian yuridis. Misalnya, seorang peneliti ingin mengetahui atau menganalisa tentang keputusan pengadilan akibat-akibat hukum adat serta pengaruhnya di masa lampau, serta ingin membuat generalisasi tentang pengaruh-pengaruh hukum tersebut atas masyarakat.

- Penelitian Biografis

Penelitian Biografis adalah metode penelitian historis yang digunaan untuk meneliti kehidupan seseorang dan hubungannya dengan masyarakat. Biasanya penelitian ini diteliti akan sifat-sifat, watak, pengaruh, lingkungan maupun pengaruh pemikiran dan ide dari subyek penelitian dalam masa hidupnya, serta pembentukan watak yang diterima semasa hayatnya. Sumber-sumber atau sejarah dalam penelitian biografis antara lain: surat-surat pribadi.

- Penelitian Bibliografis

Penelitian dengan menggunakan metode penelitian historis untuk mencari, menganalisa membuat interpretasi serta generalisasi dari fakta-fakta yang merupakan pendapat para ahli dalam suatu masalah atau suatu organisasi dikelompokkan dalam penelitian bibliografis. Penelitian ini mencakup hasil pemikiran dan ide yan telah ditulis oleh para ahli. Kerja penelitan ini termasuk menghimpun karya-karya tertentu dari serang penulis atau filosuf dan menerbitkan kembali seraya memberikan interpretasi serta generalisasi yang tepat terhadap karya-karya tersebut. 


\section{Ciri-Ciri Penelitian Historis}

1. Penelitian historis bergantung kepada data yang diobservasi orang lain daripada yang diobservasi peneliti sendiri. Data yang baik akan dihasilkan oleh kerja yang cermat yang menganalisis keotentikan, ketepatan, dan pentingnya sumber-sumbernya.

2. Berlainan dengan anggapan yang popular, penelitian historis haruslah tertib-ketat, sistematis dan tuntas; seringkali penelitian yang dikatakan sebagai suatu "penelitian historis" hanyalah koleksi informasiinformasi yang tak layak, tak readibel, dan berat sebelah.

3. "Penelitian Historis" tergantung pada dua macam data, yaitu data primer dan data sekunder. Data primer diperoleh dari sumber primer, yaitu (penulis) secara langsung melakukan observasi atau penyaksian kejadian-kejadian yang dituliskan. Data sekunder diperoleh dari sumber sekunder, yaitu peneliti melaporkan hasil observasi orang lain ya ng satukali atau lebih telah lepas dari kejadian aslinya. Di antara kedua sumber itu, sumber primer dipandang sebagai memiliki otoritas sebagai bukti tangan pertama, dan diberi prioritas dalam pengumpulan data.

4. Untuk menentukan bobot data, biasa dilakukan dua macam kritik, yaitu kritik eksternal dan kritik internal. Kritik eksternal menanyakan "Apakah dokumen relik atau otentik", sedang kritik internal menanyakan "Apabila data itu otentik, apakah data tersebut akurat dan relevan?". Kritik internal harus menguji motif, keberat-sebelahan, dan keterbatasan si penulis yang mungkin melebih-lebihkan atau mengabaikan sesuatu dan memberikan informasi yang terpalsu. Evalusi kritis inilah yang menyebabkan "peneliti historis" itu sangat tertib-ketat, yang dalam banyak hal lebih demanding daripada studi ekperimental.

5. Walaupun penelitian historis mirip dengan penelaahan kepustakaan 
yang mendahului lain-lain bentuk rancangan penelitian, namun cara pendekatan historis adalah lebih tuntas, mencari informasi dari sumber yang lebih luas. "Penelitian historis" juga menggali informasiinformasi yang lebih tua daripada yang umum dituntut dalam

penelaahan kepustakaan, dan banyak juga menggali bahan-bahan tak diterbitkan yang tak dikutip dalam bahan acuan yang standard.

\section{Sumber-Sumber Data dalam Penelitian Historis}

Oleh karena objek penelitian sejarah adalah peristiwa atau kehidupan masyarakat pada masa lampau maka yang menjadi sumber informasi harus mempunyai karakteristik yang berbeda dengan metode penelitian lainnya. Beberapa sumber tersebut di antaranya adalah sebagai berikut.

Sumber-sumber primer, yaitu data yang diperoleh dari cerita para pelaku perisriwa itu sendiri, dan atau saksi mata yang mengalami atau mengetahui peristiwa tersebut. Contoh sumber-sumber primer lainnya yang sering menjadi perhatian perhatian para peneliti di lapangan atau situs di anataranya seperti, dokumen asli, relief dan benda-benda peninggalan masyarakat zaman lampu.

Sumber informasi sekunder, yaitu informasi yang diperoleh dari sumber lain yang mungkin tidak berhubungan langsung dengan peristiwa tersebut. Sumber sekunder ini dapat berupa para ahli yang mendalami atau mengetahui peristiwa yang dibahas dan dari buku atau catatan yang berkaitan dengan peristiwa, buku sejarah, artikel dalam ensiklopedia, dan review penelitian.Dari adanya sumber primer dan sekunder ini, sebaiknya peneliti apabila mungkin lebih memberikan bobot sumber-sumber data primer lebih dahulu, baru kemudian data sekunder, data tersier, dan seterusnya.

Langkah-Langkah Dalam Penelitian Historis

Menurut M. Subana dkk. 2005: 88, adapun kerangka penelitiannya yaitu 
- Pendefinisian Masalah

- Perumusan masalah

- Pengumpulan data

- Analisis data

- Kesimpulan

Secara umum sumber informasi yang relevan dalam penenlitian sejarah dapat dikelompokkan menjadi 4 (empat) bagian berikut ini.

\section{Dokumen}

Dokumen, yaitu materi yang tertulis atau tercetak dalam bentuk buku, majalah, koran, buku catatan, dan sebagainya. Dokumen merujuk pada beberapa jenis informasi yang eksis ke dalam bentuk tertulis atau cetak.

2. Rekaman yang Bersifat Numerik

Rekaman yang bersifat numeric, yaitu rekaman yang di dalamnya terdapat bentuk-bentuk data numerik, misalnya skor tes, laporan sensus, dan sebagainya.

3. Pernyataan Lisan

Pernyataan lisan, yaitu melakukan interview dengan orang yang merupakan saksi saat peristiwa lalu terjadi. Ini merupakan bentuk khusus dari penelitian sejarah yang disebut oral history.

4. Relief

Relief, yaitu objek fisik atau karakteristik visual yang memberikan beberapa informasi tentang peristiwa masa lalu. Contohnya berupa bangunan monument, peralatan, pakaian dan sebagainya.

5. Meringkas Informasi yang Diperoleh dari Sumber Historis

Langkah ini merupakan proses me-review dan meringkas dari sumber informasi sejarah. Dalam hal ini peneliti berusaha untuk 
menentukan relevansi materi utama dengan pertanyaan atau masalah yang diteliti, yang dapat dilakukan dengan rekaman data biografi yang lengkap dari sumber, mengorganisasikan data berdasarkan kategori yang dihubungkan dengan masalah yang diteliti, dan meringkas informasi yang berhubungan fakta, jumlah, dan pertanyaan yang penting).

\section{Mengevaluasi Sumber Sejarah}

Dalam langkah ini peneliti sejarah harus mengadopsi sikap kritis ke arah beberapa atau seluruh sumber informasi. Dalam mengevaluasi sumber sejarah yang merupakan dokumen atau informasi. Dalam mengevaluasi sumber sejarah terdapat dua kritik yaitu:

1. Kritik ekstern

Kritik ekstern dilakukan utnuk menilai keaslian atau otentisitas bahan yang digunakan dalam pembuatan sumber-sumber sejarah. Sebuah dokumen yang berfungsi sebagai sumber sejarah dianggap otentik atau asli jika benar-benar hasil karya atau benda peninggalan dari pemiliknya atau pembuatannya. Untuk menentukan apakah sumber sejarah tersebut asli, seorang sejarawan harus melakukan ujian dan tes terhadap sumber sejarah tersebut. Penelitian yang dapat dilakukan oleh sejarawan, misalnya menilai tentang waktu pembuatan dokumen (hari dan tanggal) dan bahan (keras) yang dipakai untuk membuat sumber sejarah tersebut. Sejarawan juga dapat melakukan kritik ekstern dan menyelidiki tina untuk penulisan dokumen guna menemukan usia dokumen. Sejarawan dapat pula melakukan kritik ekstern dengan mengidentifikasi tulisan tangan, tanda tangan, meterai, atau jenis hurufnya.

Setelah penelitian otentisitas sumber sejarah selesai, sejarawan harus menguji secara kritis integritas sumber sejarah. Maksudnya 
sejarawan harus mengetahui apakah sumber itu tetap terpelihara keasliannya atau tidak selama proses pendokumenan atau pencatatan dari pelaku sejarah. Apabila kesaksian itu telah diubah apda suatu waktu sejak diberikan pertama kali dan perubahan-perubahan ini tidak dapat dilacak kebenarannya maka sumber sejarah tersebut sudah dianggap tidak otentik lagi dan kehilangan integritasnya. Integritas dan otentisitas sumber sejarah adalah dua aspek kritik ekstern yang sangat penting.

2. Kritik Internal

Setelah dilakukan suatu dokumen diuji melalui kritik eksternal, berikutnya dilakukan kritik internal. Walaupun dokumen itu asli, tetapi apakah mengukapkan gambaran yang benar? Bagaiaman mengenai penulis dan penciptanya? Apakah ia jujur, adil dan benar-benar memahami faktanya, dan banyak lagi pertanyaan yang bisa muncul seperti diatas. Sejarahwan harus benar-benar yakin bahwa datanya antentik dan kaurat. Hanya jika datanya autentik dan akuratlah sejarawan bisa memandang data tersebut sebagai bukti sejarah yang sangat berharga untuk ditelaah secara serius.

Kritik intern adalah usaha untuk menentukan atau menyeleksi kredibilitas sumber-sumber sejarah yang telah terkumpul. Kritik intern mengacu pada kebenaran isi dari sumber-sumber sejarah. Kritik ekstern dan kritik intern dilakukan untuk menyeleksi data yang berasal dari sumber sejarah menjadi fakta sejarah. Kritik intern dapat dilakukan dengan dua cara, yaitu menilai secara intrinsik sumbersumber sejarah dan membandingkan berbagai sumber sejarah.

Penilaian intrinsic dilakukan dengan menentukan sifat sumbersumber sejarah dan kredibilitas narasumber atau penulis sejarah. Maksudnya, sejarawan menentukan apakah keterangan atau informasi yang diberikan oleh saksi atau narasumber tersebut benar atau tidak. 
Membandingkan berbagai sumber sejarah dapat dilakukan dengan cara menguji kebenaran berbagai kesaksian sumber-sumber sejarah yang ada. Hal tersebut dilakukan dengan cara mencocokkan kesaksian satu sumber sejarah dengan sumber sejarah lainnya untuk memastikan bahwa kesaksian atau informasi yang diperoleh kredibel.

\section{Langkah-Langkah Penelitian Sejarah}

Seseorang yang akan melakukan penelitian sejarah harus memahami metode sejarah. Metode sejarah adalah proses menguji dan menganalisa secara kritis rekaman dari peninggalan masa lampau. Metode tersebut terdiri dari serangkaian langkah atau prosedur yang harus ditempuh oleh si peneliti dalam melakukan penelitiannya agar dapat berlangsung secara objektif. Dengan demikian metode sejarah dipandang sebagai alat atau sarana bagi peneliti untuk melaksanakan penelitian dan penulisan sejarah. Langkahlangkah yang dimaksud adalah:

1. Pemilihan Topik

Sebelum melakukan penelitian sejarah, langkah pertama yang harus dilakukan adalah menetapkan topik yang akan diteliti. Topik yang diteliti haruslah merupakan topik yang layak untuk dijadikan bahan penelitian dan bukan merupakan pengulangan atau duplikasi dari penelitian sebelumnya. Kelayakan topik penelitian dapat dilihat dari ketersediaan sumber yang dapat dijadikan bahan untuk penelitian. Jangan sampai kita menetapkan topik yang menarik tetapi sumbernya ternyata tidak ada.

Berbeda dengan penelitian ilmu pengetahuan lainnya, penelitian sejarah sangat tergantung kepada ketersedian sumber. Jadi topik yang diteliti harus merupakan hal yang baru dan diharapkan dapat memberikan informasi yang baru atau ditemukan teori baru. Pemilihan topik harus memperhatikan hal-hal berikut: 
- Menarik untuk diteliti

- Asli, bukan merupakan pengulangan

- Ketersediaan sumber

- Kedekatan emosional, misalnya yang berhubungan dengan lingkungan sekitar kita Pemilihan topik ini sangat penting agar peneliti lebih terarah dan terfokus pada masalahnya.

Untuk mengarahkan, dalam topik tersebut sebaiknya kita ajukan terlebih dahulu pertanyaan yang akan menjadi masalah yang akan diteliti. Pertanyaan itu meliputi: what (apa), why (mengapa), who (siapa), where (dimana), when (kapan), dan how (bagaimana). Pertanyaan itu diajukan agar penelitian lebih bersifat ilmiah. Misalnya kita akan meneliti tentang sejarah peristiwa Lengkong. Maka pertanyaan yang dapat kita ajukan adalah : Apa yang dimaksud dengan peristiwa Lengkong ? Mengapa peristiwa itu bisa terjadi ? Siapa tokoh pelaku dalam peristiwa itu ? Dimana terjadinya peristiwa itu ? Kapan terjadinya peristiwa itu ? Bagaimana jalannya peristiwa itu ?

2. Pengumpulan Data/Sumber

Setelah menetapkan topik, langkah selanjutnya adalah pengumpulan data sebagai sumber penelitian. Tahap ini disebut juga dengan heuristik (bahasa Yunani: Heureskein = menemukan). Tahap heuristik adalah tindakan sejarawan untuk mengumpulkan sumber dan jejak-jejak sejarah yang diperlukan yang terkait dengan masalah yang diteliti. Pencarian dapat dilakukan diberbagai dokumen, mengunjungi situs sejarah, atau dengan mewawancarai tokoh yang menjadi saksi atau mengetahui tentang suatu peristiwa sejarah.

Untuk memudahkan penelitian, sumber-sumber sejarah yang begitu banyak dan kompleks perlu diklasifikasikan. Sumber sejarah adalah segala sesuatu yang secara langsung maupun tidak 
menyampaikan kepada kita tentang sesuatu peristiwa dimasa lalu. Sumber sejarah merupakan bukti dan fakta adanya kenyataan sejarah. Tanpa adanya sumber, sejarawan tidak akan bisa berbicara apa-apa tentang masa lalu. Adapun sumber sejarah berasal dari bukti-bukti sejarah (evidensi), yaitu segala sesuatu yang dapat dipandang sebagai peninggalan sejarah yang dapat memberikan informasi tentang terjadinya peristiwa pada masa lampau.

Sumber tersebut dapat berupa sumber lisan, tulisan, dan bendabenda peninggalan sejarah berupa artefak, fosil, prasasti, dan lain-lain. Sumber lisan yaitu setiap tuturan lisan yang disampaikan oleh orang atau kelompok orang tentang suatu peristiwa nyata yang terjadi pada masa lampau. Sedangkan sumber tulisan, yaitu segala bentuk informasi mengenai peristiwa sejarah yang diperoleh dari berbagai tulisan. Dan sumber yang berupa benda budaya peninggalan sejarah atau artefak adalah segala macam bentuk benda budaya yang diduga pernah digunakan oleh masyarakat manusia pada masa lampau yang dapat memberi informasi tentang peristiwa masa lampau. Sumber sejarah dapat dibagi kedalam dua jenis, yaitu sumber primer dan sumber sekunder. Sumber primer adalah sumber asli, berupa kesaksian pelaku atau saksi mata yang hadir dan melihat suatu peristiwa. Sumber ini diperoleh dan dihasilkan dari sisa atau jejak dan orang yang sejaman dengan peristiwa itu. Sumber sekunder adalah sumber yang diperoleh dari tangan kedua, yaitu orang yang tahu suatu peristiwa, tetapi tidak hadir dan melihat peristiwa itu berlangsung. Dapat pula ditambahkan bahwa sumber sejarah dapat berupa sumber formal dan non formal.

Menemukan sumber sejarah tidaklah mudah, mengingat ada peristiwa yang sedikit sekali meninggalkan jejak, bahkan karena sesuatu hal tidak meninggalkan jejak sama sekali. Namun ada pula 
peristiwa yang meninggalkan jejak yang melimpah. Selain itu sumber sejarah ada yang dengan cepat ditemukan dan diketahui, tetapi ada pula yang setelah beberapa waktu yang lama kemudian baru diketahui. Hal ini bisa terjadi karena jarak waktu. Semakin dekat jarak waktu antara sipeneliti dengan peristiwa sejarah, semakin banyak sumber sejarah yang dapat diperoleh. Sebaliknya, semakin jauh jarak waktunya, semakin langka dan sedikit sumber sejarah yang didapatkan.

3. Verifikasi

Sebelum data dan sumber sejarah yang terkumpul digunakan sebagai pendukung penelitian, terlebih dahulu dilakukan Verifikasi (pengujian), baik dari segi kebenaran materi atau isi maupun keaslian dari data sumber tersebut. Dalam ilmu sejarah tahap ini disebut kritik. Kritik sejarah tersebut meliputi kritik intern yaitu kritik terhadap isi dan materi, dan kritik ekstern yaitu kritik terhadap keaslian sumber-sumber tersebut. Kritik intern adalah penilaian keakuratan atau keautentikan terhadap materi sumber sejarah.

Didalam proses analisa terhadap suatu dokumen, sejarawan harus selalu memikirkan unsur-unsur yang relevan didalam dokumen itu sendiri secara keseluruhan. Unsur didalam dokumen dianggap relevan dan dapat dipercaya (kredibel) apabila unsur itu paling dekat dengan apa yang telah terjadi. Identifikasi terhadap sipembuat dokumen atau sumber sejarah pun perlu dilakukan untuk menguji keautentikannya. Kritik ekstern umumnya menyangkut keaslian bahan yang digunakan dalam pembuatan sumber sejarah, seperti prasasti, dokumen, dan naskah. Untuk membedakan itu suatu tipuan dari dokumen asli, sejarawan dapat menggunakan pengujian yang biasa digunakan didalam penyelidikan polisi dan kehakiman.

Bentuk penelitian yang dapat dilakukan sejarawan misalnya tentang waktu pembuatan dokumen, atau penelitian tentang bahan 
materi pembuatan.

4. Interpretasi

Setelah memberikan kritik terhadap sumber, langkah berikutnya adalah memberikan penafsiran atau interpretasi. Pada tahap ini dapat berlaku sifat subjektifitas, karena sejarawan akan melihat sumber sejarah dari sudut pandang yang berbeda. Perbedaan penafsiran terhadap suatu peristiwa yang sama mungkin juga terjadi. Perbedaan tersebut terjadi karena diantara para sejarawan memiliki pandangan, wawasan, ketertarikan, ideology, kepentingan, latar belakang sosial dan tujuan yang berbeda.

Interpretasi pada dasarnya merupakan langkah yang dilakukan dalam menjawab permasalahan dari topik yang diteliti. Fakta yang dihasilkan melalui kritik harus dihubungkan antara yang satu dengan yang lainnya, terutama dalam konteks hubungan sebab akibat atau adanya hubungan yang sangat berarti/signifikan.

5. Historiografi atau penulisan sejarah

Merupakan langkah bagaimana sejarawan mengkomunikasikan hasil penelitiannya untuk diketahui umum. Sejarawan melakukan penyusunan kisah sejarah sesuai dengan norma-norma dalam disiplin ilmu sejarah. Diantaranya yang penting adalah harus kronologis. Disamping itu harus diupayakan seobjektif mungkin. Dalam menulis sejarah berarti seorang sejarawan merekonstruksi sumber-sumber sejarah yang telah ditemukannya menjadi suatu cerita sejarah.

Kemampuan menulis merupakan syarat yang penting bagi seorang sejarawan. la harus mampu berimajinasi dalam menyusun cerita sejarah. Kemampuan berimajinasi dalam menulis menunjukan bahwa menulis sejarah mengandung unsur seni. Bahkan apabila tulisan sejarah itu mampu mengajak pembacanya ikut menerawang kemasa silam dapat mengandung kesan berekreasi kemasa lampau. 
Bentuk-bentuk historiografi antara lain dapat berupa: Narasi yang isinya lebih banyak bercerita sesuai dengan apa yang diinformasikan oleh sumber sejarah. Deskriptif yang isinya lebih detail dan kompleks dibandingkan dengan narasi. Dan Analistis, yang isinya lebih banyak berorientasi pada penelaahan masalah.

Sehingga tidak sekedar bercerita tetapi banyak menjawab pertanyaan-pertanyaan yang mendalam dengan tinjauan berbagai aspek. Penulisan yang baik adalah gabungan antar unsur naratif, deskriptif dan analitis. Bentuk gabungan ini akan menampilkan unsur cerita, detail sumber dan analisa terhadap peristiwa sejarah. Bentukbentuk penelitian Dilihat dari teknik pengumpulan data, penelitian sejarah dibagi dalam dua bentuk, yaitu penelitian Lapangan dan penelitian kepustakaan.

- Penelitian Lapangan Dalam melakukan penelitian lapangan seorang sejarawan datang ketempat terjadinya peristiwa sejarah atau tempat ditemukannya peninggalan-peninggalan sejarah (situs). Bila peninggalan tersebut telah disimpan di museum, maka penelitian dilakukan di museum. Dan apabila benda-benda peninggalan itu masih terpendam didalam tanah, maka sejarawan harus melakukan penggalian atau ekskavasi. Jika seorang sejarawan memerlukan keterangan langsung dari pelaku atau saksi sejarah yang masih hidup sebagai sumber lisan maka bisa dilakukan melalui metode wawancara (interview).

- Penelitian kepustakaan Penelitian kepustakaan disebut juga dengan penelitian dokumenter. Dalam melakukan penelitian dokumenter, seorang peneliti memfokuskan perhatiannya untuk memperoleh datadata tertulis yang disimpan di museum atau perpustakaan. Untuk mendapatkan data dan informasi yang benar dan akurat, peneliti dapat 
melakukan studi komparatif, yaitu membandingkan sumber yang satu dengan sumber yang lainnya yang berkenaan dengan suatu hal.

\section{Kelebihan dan Kelemahan dalam Penelitian Historis}

Kelebihan penelitian historis adalah sebagai berikut:

- Tidak terlalu melibatkan peneliti secara fisik

- Tidak ada kekhawatiran terjadinya interaksi antara peneliti dengan subyek

- Mudah dalam mencari sumber data

- Dapat mencari data secara lebih tuntas dalam menggali informasi yang diperlukan dalam proses penelitian

- Sumber data sudah dinyatakan secara difinitif baik nama pengarang, tempat dan waktu.

Kelemahan penelitian historis adalah sebagai berikut:

- Metode sejarah banyak menggantungkan diri pada data yang diamati oleh orang lain dimasa lampau

- Data yang digunakan banyak tergantung pada data primer

- Metode ini mencari data secara lebih tuntas serta menggali informasi yang lebih tua yang tidak diterbitkan ataupun tidak dikutip dalam bahasa acuan yang standart. 


\section{DAFTAR PUSTAKA}

Arikunto, Suharsimi. Prosedur Penelitian Suatu Pendekatan Praktik. Jakarta: Rineka Cipta

Azwar, Saifudddin. 2011. Metode Penelitian. Yogyakarta: Pustaka Belajar Cresswell, John W. 2007, Qualitative Inquiry \& Research Design; Chosing Among Five Approaches.

Daud, Safari. 2013, Antara Biografi dan Historiografi ( studi 36 buku biografi di Indonesia ) Analisis, Volume XIII, Nomor 1, juni.

Eko Ganis Sukoharsono, Alternatif Riset Kualitatif Sains Akuntansi: Biografi, Phenomenologo, Grounded Theory. Critical Ethnografi dan Case Study, Fakultas Ekonomi Brawijaya.

Era, Wiloka. 2012. Langkah-Langkah Penelitian Sejarah. 1-4 
Finley, L. 2006, Going Exploring" :The Nature of Qualitative Research", Qualitative Research for Allied Health Professionals: Challenging Choices. Edited by Linda Finlay and Clarie Balinger. New Nyork: Jhon Wiley \& Son.

Gonggong, Anhar. 2004. Abdul Qahhar Mudzakar: dari patriot hingga pemberontak, Yogyakarta: Ombak.

Jaelani, M Syahrul. 2013, Ragam Penelitian Qualitative . Jurnal Edu-Bio; Vol 4. Kartodirdjo, Sartono. 1993. Pendekatan Ilmu Sosial dalam Metodologi Sejarah. Jakarta: Gramedia.

Kayla, Anjeli. 2013. Makalah Penelitian Historis. 3-4

Klinken, Gerry van. 2008. Aku yang Berjuang; Sebuah Sejarah Penulisan Tentang Diri Sendri pada Masa Orde Baru. Dalam Henk Sehulte, Bambang Purwanto dan Ratna Saptari (ed), Perspektif Baru Penulisan Sejarah Indonesia. Jakarta. Yayasan Obor Indonesia dan KITLV.

Kuntowijoyo. 2003. Metodologi Sejarah. Yogyakarta: Tara Wacana

Rosenthal, Franz. 2011. A History of Muslim Historiography, Leiden: E.J. Brill, Rusandi, M Arli. 2012. Metode Penelitian history dan Deskriptif. 6-10

Sekar, Seruni Laras. 2016. Metode Penelitian Biografi dalam Pendekatan Penelitian Kualitatif. John W. Creswell. 1-2

Smith, Louis M. 2009. Metode Biografis dalam Norman K. Denzin dan Yvonna S, Lincoln, Hnadbook of Qualitative Research. Terj. Dariyanto, Dkk, Yogyakarta: Pustaka Pelajar.

Suryana, 2010, Metodologi Penelitian Model Praktis Penelitian Kuantitatif Kualitatif, Universitas Pendidikan Indonesia.

Suyabrata, Sumardi. 2012. Metodologi Penelitian. Jakarta: Rajawali Pers Vazmae. Dasar-Dasar Penelitian Sejarah. 3-4 
